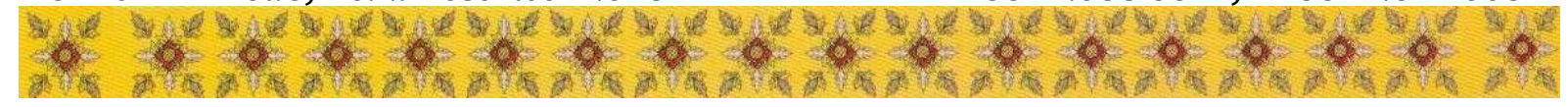

\title{
PENGARUH AKUNTABILITAS DAN TRANSPARANSI PENGELOLAAN KEUANGAN DAERAH TERHADAP KINERJA INSTANSI INSPEKTORAT ACEH
}

\author{
Zulkifli Umar ${ }^{1}$,Cut Fittika Syawalina' ${ }^{2}$, dan Khairunnisa ${ }^{3}$ \\ 1,2,3 Fakultas Ekonomi Universitas Muhammadiyah Aceh \\ 12ulkifliumar@gmail.com
}

\begin{abstract}
This research was conducted to determine the effect of accountability and transparency on the performance of the Aceh Inspectorate agencies. The object of this research is transparency, accountability and agency performance. The number of samples in this study were 42 respondents. Data collected using questionnaires with units of Likert scale units. The analytical equipment used in analyzing the data is multiple linear regression. Simultaneous results show that accountability and transparency jointly influence the performance of the Aceh Inspectorate Office, accountability partially influences the performance of the Aceh Inspectorate Office agencies with a regression coefficient of 0.155 and transparency has a partial effect on the performance of agency auditors in the Aceh Inspectorate Office with a regression coefficient of 0.137 . The results of this study imply that the accountability and transparency possessed by auditors will have a real influence in improving agency performance for auditors of the Aceh Inspectorate Office.
\end{abstract}

Key words: transparency, accountability and agency performance

\begin{abstract}
Abstrak
Penelitian ini dilaksanakan untuk mengetahui pengaruh akuntabilitas dan transparansi terhadap kinerja instansi Inspektorat Aceh. Objek penelitian ini adalah transparansi, akuntabilitas dan kinerja instansi. Jumlah sampel dalam penelitian ini adalah sebanyak 42 orang responden. Data yang dikumpulkan menggunakan kuesioner dengan satuan pengukuran satuan skala likert. Peralatan analisis yang digunakan dalam menganalisis data adalah regresi linier berganda. Hasil secara simultan menunjukkan bahwa akuntabilitas dan transparansi secara bersama-sama berpengaruh terhadap kinerja instansi Kantor Inspektorat Aceh, akuntabilitas secara parsial berpengaruh terhadap kinerja instansi Kantor Inspektorat Aceh dengan nilai koefisien regresi sebesar 0,155 dan transparansi berpengaruh secara parsial terhadap kinerja instansi para auditor pada Kantor Inspektorat Aceh dengan nilai koefisien regresi sebesar 0,137. Hasil penelitian ini memberikan implikasi bahwa akuntabilitas dan transparansi yang dimiliki oleh auditor akan memberikan pengaruh nyata dalam meningkatkan kinerja instansi bagi auditor Kantor Inspektorat Aceh.
\end{abstract}

Kata Kunci: akuntabilitas transparansi dan kinerja instansi

\section{PENDAHULUAN}

Akuntansi dan pelaporan keuangan suatu unit pemerintahan, menyajikan informasi keuangan yang berguna untuk membuat keputusan ekonomi, politik dan sosial. Pemakai informasi keuangan unit pemerintah adalah pemerintah, investor dan kreditor, masyarakat, pihak-pihak lain yang berkepentingan terhadap laporan keuangan tersebut. Informasi keuangan yang dibutuhkan adalah informasi mengenai apakah operasi keuangan dijalankan dengan baik, apakah pelaporan keuangan dari suatu audit entitas disajikan secara wajar dan apakah entitas 
tersebut telah mentaati hukum dan peraturan yang ada, dan untuk melihat akuntabilitas secara riel, menilai integritas, kinerja dan pertanggungjawaban aktivitas pemerintah. Guna memenuhi kebutuhan para pemakai tersebut, informasi keuangan yang disajikan dalam laporan keuangan perlu diaudit, hal tersebut dijalankan oleh auditor dalam melakukan pemeriksaan untuk mencapai kualitas audit yang baik.Dalam rangka meningkatkan kinerja instansi Inspektorat Aceh, diperlukan adanya prinsip akuntabilitas dan transparansi dalam pengelolaan keuangan daerah. Akuntabilitas adalah suatu konsep terkait dengan mekanisme pertanggungjawaban dari satu pihak ke pihak yang lain.

Fenomena yang terjadi pada Kantor Inspektorat Aceh berdasarkan kinerja instansi tersebut masih belum memenuhi harapan publik Aceh yaitu terciptanya akuntabilitas dalam pengelolaan keuangan pada lembaga pemerintah dan masih kurangnya prinsip transparansi dalam memberikan informasi kepada masyarakat berkaitan dengan kinerja Kantor Inspektorat Aceh yaitu melakukan pengawasan dan audit keuangan pada setiap kegiatan operasional lembaga Pemerintah Aceh. Asumsi ini diperkuat melalui kinerja instansi Kantor Inspektorat Aceh berdasarkan penyerapan atau pencapaian anggaran yang telah ditetapkan pada tahun anggaran sejak tahun 2014 sampai tahun 2016 tidak dapat dicapai sesuai target yaitu pencapaian 100\%. Penyerapan anggaran digunakan untuk membiayai kegiatan pada seluruh SKPA dan SKPK di Aceh yang dianggap bermasalah. Hal ini disebabkan oleh masih lemahnya penerapan prinsip transparansi keuangan yang masih belum berjalan dengan harapan masyarakat yaitu masyarakat ingin mengetahui secara pasti tentang penggunaan dana publik dan bentuk pertanggungjawaban dana publik yang telah digunakan oleh Kantor Inspektorat Aceh. Dalam konteks Pemerintahan, transparansi dan akuntabilitas merupakan salah satu ciri "good governance", dimana pemikiran tersebut bersumber dari pemikiran bahwa pengelolaan administrasi publik merupakan isu utama dalam pencapaian "Clean Government" atau pemerintahan yang bersih. Transparansi dan akuntabilitas dapat dikaitkan dengan reformasi saat ini yang menghendaki pemberantasan KKN, khususnya korupsi. Sehingga dengan adanya kinerja sistem informasi keuangan daerah yang akurat akan menciptakan pemerintah yang transparan dan akuntabel dalam setiap kegiatan.

\section{TINJAUAN PUSTAKA}

\section{Good Governance}

Tata kelola pemerintahan yang baik (good governance) merupakan masalah yang paling penting dalam pengelolaan administrasi publik dewasa ini. Tuntutan gencar yang dilakukan oleh 
masyarakat kepada pemerintah untuk melaksanakan penyelanggaraan pemerintah yang baik adalah sejalan dengan meningkatkannya tingkat pengetahuan masyarakat disamping adanya pengaruh globalisasi.Ganie-Rochman (2012:145) menyebutkan governance adalah mekanisme pengelolaan sumber ekonomi dan sosial yang melibatkan pengaruh sektor negara dan sektor non-pemerintah dalam suatu usaha kolektif. Definisi ini mengasumsikan banyak aktor yang terlibat dimana tidak ada yang sangat dominan yang menentukan gerak aktor lain. Sedangkan menurut dokumen United Nations Development Program(UNDP) yang dikutip oleh Renyowijoyo (2013: 18) mendefinisikan governance sebagai " the exercise of political, economic, and administrative authority to manage a nation's affair at all levels".

\section{Akuntabilitas}

Mardiasmo (2012:20) mendefinisikan bahwa akuntabilitas publik merupakan kewajiban pihak pemegang amanah (agent) untuk memberikan pertanggungjawabandan mengungkapkan segala aktivitas dan kegiatan yang menjadi tanggungjawabnya kepada pihak pemberi amanah (principal) yang memiliki hak dan kewenangan untuk meminta pertanggungjawaban tersebut. Selanjutnya akuntabilitas dapat diartikan sebagai bentuk kewajiban memper-tanggungjawabkan keberhasilan atau kegagalan pelaksanaan misi organisasi dalam mencapai tujuan dan sasaran yang telah ditetapkan sebelumnya, melalui suatu media pertanggungjawaban yang dilaksanakan secara periodik, (Mardiasmo:2014:20).

Menurut Krina, (2012:133) menjelaskan akuntabilitas sebagai pertanggungjawaban pihak yang diberi mandat untuk memerintah kepada mereka yang memberi mandat itu. Lebih lanjut Krina juga menyebutkan bahwa akuntabilitas bermakna pertanggungjawaban dengan menciptakan pengawasan melalui distribusi kekuasaan pada berbagai lembaga pemerintah sehingga mengurangi penumpukan kekuasaan sekaligus menciptakan kondisi saling mengawasi (checks and balances system).

\section{Transparansi}

Transparansi merupakan salah satu prinsip dari good governance. Transparansi dibangun atas dasar arus informasi yang bebas, seluruh proses pemerintahan, lembaga-lembaga dan informasi perlu diakses oleh pihak-pihak yang berkepentingan, dan informasi yang tersedia harus memadai agar dapat dimengerti dan dipantau (Coryanata,2015:99).

Krina (2012:133) menyatakan bahwa transparansi adalah prinsip yang menjamin akses atau kebebasan bagi setiap orang untuk memperoleh informasi tentang penyelenggaraan pemerintahan yaitu informasi tentang kebijakan, proses pembuatan dan pelaksanaannya, serta hasil-hasil yang dicapai. Selanjutnya, Op.cit yang dikutip oleh Krina (2012:133) juga 
menjelaskan bahwa prinsip transparansi memiliki dua aspek, yaitu: (1) komunikasi publik oleh pemerintah, dan (2) hak masyarakat terhadap akses informasi. Transparansi yakni adanya kebijakan terbuka bagi pengawasan. Sedangkan yang dimaksud dengan informasi adalah sesuatu mengenai setiap aspek kebijakan pemerintah yang dapat dijangkau oleh publik. Keterbukaan informasi diharapkanakan menghasilkan persaingan politik yang sehat, toleran, dan kebijakan dibuat berdasarkan pada preferensi publik.

Lebih jauh lagi,transparansi juga terdapat dalam PP. Pasal 4 PP No. 58 Tahun 2013 menyebutkan bahwa pengelolaan keuangan daerah dilakukan secara tertib,taat pada peraturan perundang-undangan yang berlaku,efisien, transparan, dan bertanggung jawab dengan memperhatikan asas keadilan dan kepatuhan.

\section{Kinerja Instansi}

Kinerja instansi atau organisasi merupakan indikator tingkatan prestasi yang dapat dicapai dan mencerminkan keberhasilan suatu organisasi, serta merupakan hasil yang dicapai dari perilaku anggota organisasi.Kinerja bisa juga dikatakan sebagai sebuah hasil (output) dari suatu proses tertentu yang dilakukan oleh seluruh komponen organisasi terhadap sumbersumber tertentu yang digunakan (input). Selanjutnya, kinerja juga merupakan hasil dari serangkaian proses kegiatan yang dilakukan untuk mencapai tujuan tertentu organisasi. Bagi suatu organisasi, kinerja merupakan hasil dari kegiatan kerjasama diantara anggota atau komponen organisasi dalam rangka mewujudkan tujuan organisasi.

Supriyanto (2015 : 40) menyatakan bahwa kinerja perusahaan tidak cukup hanya diukur berdasarkan laba akuntansi saja, karena laba akuntansi tidak mempunyai makna riil apabila apabila tidak didukung oleh kemampuan perusahaan dalam meningkatkan nilai tambah secara ekonomis.

Mangkunegara (2010:15) menyebutkan bahwa kinerja dibedakan menjadi 2 (dua), yaitu:

1. Kinerja individu

Kinerja individu adalah hasil kerja karyawan baik dari segi kualitas maupun kuantitas berdasarkan standar kerja yang telah ditentukan.

2. Kinerja organisasi

Kinerja organisasi adalah gabungan dari kinerja individu dengan kinerja kelompok.

\section{Hubungan Akuntabilitas Dengan Kinerja Instansi}

Akuntabilitas merupakan kemauan memberikan penjelasan dan justifikasi keinginan dan perbuatan kepada yang berkepentingan (Hunt, 2006:43). Berbeda dengan transparansi yakni mempertanggungjawabkan apa yang telah dilakukan dengan memberi informasi yang relevan 
atau laporan yang terbuka pada pihak luar atau organisasi mandiri (legislator, auditor, publik) dan dipublikasikan (Haryatmoko, 2013:112). Pada akhirnya, unsur akuntabilitas menjadi suatu kebutuhan didalam pengelolaan pemerintah termasuk bidang keuangan (Hudayah, 2012), khususnya dalam hal penyusunan anggaran berbasis kinerja. Dengan adanya penerapan akuntabilitas akan tercipta kinerja instansi yang lebih baik.

Kinerja instansi pemerintah berkaitan erat dengan akuntabilitas dan transparansi. Penerapan berbagai aturan perundang-undangan yang ada terkait dengan penerapan konsep akuntabilitas dan transparansi dalam pengelolaan keuangan diharapkan dapat mewujudkan pengelolaan pemerintah daerah yang baik dan berpihak kepada rakyat. Implementasi akuntabilitas dan transparansi dalam pengelolaan keuangan daerah ini diharapkan mampu meningkatkan kinerja pemerintah daerah.

\section{Hubungan Transparansi Dengan Kinerja Instansi}

Kurniawan (2013:145) mengemukakan, bahwa transparansi terwujud apabila pemerintah bersedia untuk menginformasikan kepada masyarakat/DPRD bagaiamana dana publik digunakan/dikelola dalam kegiatan dan program pemerintah. Penelitian yang dilakukan oleh Hadyrianto (2012:55) yang berjudul Pengaruh Akuntabilitas, dan Transparansi pada Pengelolaan Anggaran di Universitas Bina Nusantara, menunjukkan bahwa transparansi berpengaruh positif terhadap pengelolaan anggaran.

Berdasarkan uraian sebelumnya, maka kerangka penelitian dapat dilihat sebagai berikut:

\section{Variabel Independen}

\section{Variabel Dependen}

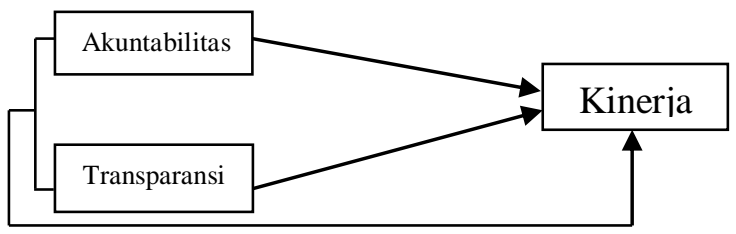

Gambar 2 Kerangka Penelitian

Prinsip transparansi memiliki dua aspek dalam mewujudkan pemerintah yang terbuka akan informasi-informasi mengenai kebijakan yang dijalankan oleh pemerintah daerah, yaitu komunikasi publik oleh pemerintah dan hak masyarakat terhadap akses informasi. Keduanya akan sangat sulit dilakukan jika pemerintah tidak menangani kinerjanya dengan baik. Manajemen kinerja yang baik adalah titik awal dari transparansi. Transparansi harus seimbang dengan kebutuhan akan kerahasiaan lembaga maupun informasi-informasi yang mempengaruhi 
hak privasi individu. Pemerintah daerah seharusnya perlu menyiapkan kebijakan yang jelas tentang caramen dapatkan informasi (Krina, 2013:134).

Hipotesis yang diuji dalam penelitian ini adalah:

$\mathrm{H}_{1}$ : Akuntabilitas dan transparansi secara simultan berpengaruh terhadap kinerja instansi Inspektorat Aceh

$\mathrm{H}_{2}$ : Akuntabilitas berpengaruh terhadap kinerja instansi Inspektorat Aceh

$\mathrm{H}_{3}$ : Transparansi berpengaruh terhadap kinerja instansi Inspektorat Aceh

\section{METODE PENELITIAN}

\section{Populasi dan Sampel Penelitian}

Populasi dalam penelitian ini adalah pegawai yang bekerja pada Kantor Inspektorat Aceh. Jumlah populasi dalam penelitian ini berjumlah sebanyak83 orang, namun dalam penelitian ini responden dalam penelitian ini ditentukan sebesar 50\% karena berdasarkan pendapat Sekaran (2015:132) bahwa penelitian kuantitatif dapat mengambil 10 - 100\% dari total populasi yang berjumlah diatas 83 orang, sehingga penelitian ini mengambil sebesar 42 orang. Populasi dan sampel dijelaskan pada Tabel 1.

Tabel 1. Populasi Penelitian

\begin{tabular}{cccc}
\hline No & Jabatan & Populasi & Sampel \\
\hline 1. & Kepala Unit Pemeriksa & 4 & 2 \\
2. & Pemeriksa Muda & 31 & 16 \\
3. & Jumlah & 48 & 24 \\
& 83 & 42 \\
\hline \multicolumn{2}{l}{ Sumber : Kantor Inspektorat Aceh (2018) }
\end{tabular}

\section{Teknik Pengumpulan Data}

Data dalam penelitian ini menggunakan data primer, yang didapat dengan melakukan penelitian lapangan yaitu dengan cara melakukan penelitian secara langsung terhadap responden yang dilakukan dengan menggunakan kuesioner. Kuesioner didistribusikan dengan cara disampaikan langsung oleh peneliti kepada responden yang selanjutnya akan dihubungi beberapa hari kemudian untuk mengambil kembali kuesioner yang telah diisi.

Variabel yang digunakan dalam penelitian ini ada 2 (dua), yaitu :

\section{Variabel Terikat (Dependent Variable)}

Variabel terikat (Y) adalah variabel yang dipengaruhi oleh variabel lain. Dalam penelitian ini yang menjadi dependent variable adalah kinerja instansi yaitu indikator pencapaian hasil 
dari organisasi yang dapat dicapai dan mencerminkan keberhasilan suatu organisasi, serta merupakan hasil yang dicapai dari perilaku anggota organisasi, (Robbins, 2013).

\section{Variabel Bebas (Independent Variabel)}

Sekaran (2015 : 117) Variabel bebas adalah variabel yang memengaruhi variabel terikat, entah secara positif atau negatif. Variabel independent dalam penelitian ini diwakili oleh 3 (tiga) dimensi yaitu:

a. Akuntabilitas $\left(\mathrm{X}_{1}\right)$

Merupakan kewajiban penerima tanggungjawab untuk rnengelola sumber daya, melaporkan, dan mengungkapkan segala aktivitas dan kegiatan yang berkaitan dengan penggunaan sumber daya publik kepada pihak pemberi mandate (principal) (Mahmudi, 2013). Akuntabilitas diukur dengan 5 (lima) item pertanyaan menggunakan skala interval Likert 5 (lima) poin. Jadi indikator yang digunakan adalah tugas dilaksanakan dengan baik, hukuman/sanksi, pelayanan lebih baik, tanggung jawab dan tepat waktu.

b. Variabel Transparansi $\left(\mathrm{X}_{2}\right)$

Merupakan Adanya kebijakan terbuka bagi pengawasan. Menjamin akses atau kebebasan bagi setiap orang untuk memperoleh informasi tentang penyelenggaraan pemerintah, yakni informasi tentang kebijakan, proses pembuatan dan pelaksanaannya, serta hasil-hasil yang dicapai. (Krina: 2013).Transparansi diukur dengan 3 (tiga) item pertanyaan menggunakan skala interval Likert 5 (lima) poin. Jadi indikator yang digunakan adalah keterbukaan, aksesabilitas dan publikasi.

\section{Teknik Analisa Data}

Peralatan analisis regresi linear berganda merupakan suatu teknik untuk membangun model matematis yang dapat digunakan untuk menganalisis pengaruh satu atau beberapa variabel indepeden terhadap variabel dependen. Dalam hubungan dengan penelitian ini variabel independen adalah akuntabilitas dan transparansi $(\mathrm{X})$ sedangkan variabel dependent-nya adalah kinerja instansi (Y) dengan persamaan estimasinya adalah : (Santoso, 2015 : 290).

$$
\mathrm{Y}=\mathrm{a}+\mathrm{b}_{1} \mathrm{X}_{1}+\mathrm{b}_{2} \mathrm{X}_{2}+\mathrm{e}
$$

Keterangan :

$\begin{array}{ll}\mathrm{Y} & =\text { Kinerja Instansi } \\ \mathrm{X}_{1} & =\text { Akuntabilitas } \\ \mathrm{X}_{2} & =\text { Transparansi } \\ \mathrm{a} & =\text { Konstanta } \\ \mathrm{b}_{1-1} \mathrm{~b}_{2} & =\text { Parameter } \\ \mathrm{e} & =\text { Error Term }\end{array}$


HASIL ANALISIS

\section{Persepsi Terhadap Akuntabilitas}

Berdasarkan hasil penelitian bahwa variabel akuntabilitas Kantor Inspektorat Aceh diperoleh nilai rerata sebesar 4.16 yang bermakna bahwa akuntabilitas bagi seorang auditor ini sudah relatif baik, hal ini dapat dilihat dari pernyataan mengenai proses pembuatan keputusan secara tertulis, akurasi dan kelengkapan informasi tentang program, kejelasan sasaran kebijakan yang diambil dan didokumentasikan, kelayakan dan konsistensi dari target operasional, adanya pelaporan tentang setiap program, dan adanya evaluasi terhadap keberhasilan program. Berdasarkan pernyataan responden dapat dijelaskan bahwa responden dalam penelitain ini menyatakan setuju bahwa penerapan prinsip akuntabilitas akan memberikan pengaruh terhadap peningkatan kinerja instansi Inspektorat Aceh, terutama dalam mengawasi keuangan Pemerintah Daerah Aceh.

\section{Persepsi Terhadap Transparansi}

Transparansi merupakan adanya kebijakan terbuka bagi pengawasan. Menjamin akses atau kebebasan bagi setiap orang untuk memperoleh informasi tentang penyelenggaraan pemerintah, yakni informasi tentang kebijakan, proses pembuatan dan pelaksanaannya, serta hasil-hasil yang dicapai. Berdasarkan hasil penelitian dapat dijelaskan bahwa variabel transparansi diperoleh nilai rerata sebesar 4.15, atau responden menyatakan setuju bahwa transparansi yang diterapkan oleh pegawai pada Kantor Inspektorat Aceh berpengaruh dalam meningkatkan kineja instansi Kantor Inspektorat Aceh. Hal ini dapat dilihat dari pernyataan responden mengenai adanya penyebarluasan informasi mengenai suatu keputusan, adanya akses publik pada informasi atas suatu keputusan, adanya sistem informasi manajemen dan monitoring hasil, adanya penyediaan informasi yang jelas tentang prosedur, adanya penyediaan informasi yang jelas tentang biaya biaya, dan penyediaan informasi yang jelas tentang tanggung jawab.

Berdasarkan pernyataan di atas dapat dijelaskan bahwa penerapan prinsip transparansi yang dilakukan oleh pegawai pada Intansi Kantor Inspektorat Aceh mampu memberikan pengaruh dalam meningkatkan kinerja Inspektorat Aceh, terutama dalam adanya keterbukaan informasi kepada publik. Hal ini mengindikasikan bahwa dengan adanya prinsip transparansi atau keterbukaan informasi kepada publik akan menjadikan organsiasi memiliki kinerja yang baik.

\section{Persepsi Terhadap Kineja instansi Kantor Inspektorat Aceh}

Kinerja instansi merupakan indikator tingkatan prestasi yang dapat dicapai dan 
mencerminkan keberhasilan suatu organisasi, serta merupakan hasil yang dicapai dari perilaku anggota organisasi.

Berdasarkan hasil penelitian dapat dijelaskan bahwa variabel kinerja instansi diperoleh nilai rerata sebesar 4.19, atau responden menyatakan setuju bahwa kinerja instansi yang dimiliki oleh auditor sudah sesuai. Hal ini juga dapat dilihat dari pernyataan responden mengenai adanya tanggung jawab petugas terhadap setiap laporan yang diterima, adanya kecepatan pelayanan yang menjadi standar organisasi dalam memberikan pelayanan, adanya sikap sopan dan keramahan petugas dalam memberikan pelayanan kepada masyarakat, kepastian biaya pelayanan yang diberikan oleh petugas berdasarkan ketentuan, kepastian jadwal pelayanan sudah tertulis secara jelas di papan pengumuman, kenyamanan lingkungan kantor sangat dijaga oleh pihak organisasi dan keamanan pelayanan menjadi prioritas utama organisasi dalam memberikan pelayanan. Berdasarkan pernyataan diatas dapat dijelaskan bahwa kinerja instansi Inspektorat Aceh sudah berjalan dengan baik sesuai dengan harapan publik, hal ini tidak terlepas dari adanya penerapan prinsip akuntabilitas dan prinsip transparansi yang dilakukan oleh instansi tersebut.

\section{Pembahasan}

Hasil regresi berganda di dapat nilai konstanta sebesar 2.359 artinya jika akuntabilitas $\left(\mathrm{X}_{1}\right)$ dan transparansi $\left(\mathrm{X}_{2}\right)$, dianggap konstan, maka besarnya kinerja instansi pada Kantor Inspektorat Aceh adalah sebesar 2.359 pada satuan skala likert. Koefisien regresi akuntabilitas sebesar 0.155. Artinya bahwa setiap 100\% perubahan (perbaikan, karena tanda +) dalam variabel akuntabilitas, maka secara relatif akan meningkatkan kinerja instansi pada Kantor Inspektorat Aceh sebesar15.5\%, dengan demikian akuntabilitas yang ada pada Kantor Inspektorat Aceh, dapat berpengaruh terhadap kinerja instansi pada Kantor Inspektorat Aceh.

Koefisien regresi transparansi sebesar 0.137. Artinya setiap 100\% perubahan (perbaikan, karena tanda +) dalam variabel transparansi, maka secara relatif akan meningkatkan kinerja instansi pada Kantor Inspektorat Aceh sebesar 13.7\%, jadi dengan adanya transparansi, maka secara relatif akan dapat meningkatkan kinerja instansi pada Kantor Inspektorat Aceh. Jadi dengan adanya penerapan prinsip transparansi, maka akan berpengaruh terhadap peningkatan kinerja instansi pada Kantor Inspektorat Aceh.

Berdasarkan hasil analisis di atas dapat diketahui bahwa dari ketiga variabel yang diteliti, ternyata variabel akuntabilitas $\left(\mathrm{X}_{1}\right)$ mempunyai pengaruh dominan terhadap kinerja instansi pada Kantor Inspektorat Aceh, dengan nilai koefisien regresi sebesar 0.155, kemudian diikuti oleh variabel transparansi $\left(\mathrm{X}_{2}\right)$ dengan koefisien sebesar 0.137. Hal ini mengindikasikan bahwa 


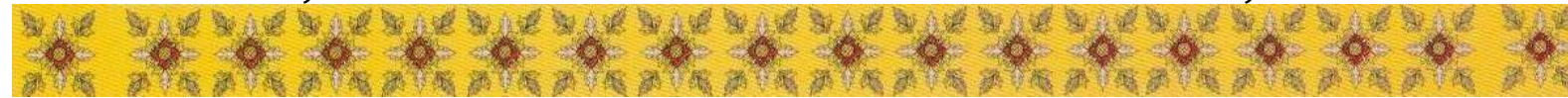

akuntabilitas yang ada dilingkungan KantorInspektorat Aceh, dapat meningkatkan kinerja instansi secara nyata.

Penelitian ini memberikan indikasi bahwa akuntabilitas yang dimiliki oleh pegawai pada Kantor Inspektorat Aceh mempunyai dampak terhadap peningkatan kinerja instansi baik secara langsung maupun tidak langsung karena pegawai akan melakukan pekerjaan dan mempertanggungjawabkan hasil kerja tersebut kepada publik.

Transparansimerupakan kebijakan terbuka bagi pengawasan. Menjamin akses atau kebebasan bagi setiap orang untuk memperoleh informasi tentang penyelenggaraan pemerintah. Jadi dengan adanya prinsip transparansi akan memberikan dampak terhadap peningkatan kinerja instansi di masa yang akan datang.

\section{KESIMPULAN}

Berdasarkan hasil penelitian dan rumusan masalah yang telah dilakukan sebelumnya, maka dapat dilihat beberapa kesimpulan sebagai berikut:

1. Hasil penelitian membuktikan bahwa akuntabilitas dan transparansi secara bersama-sama berpengaruh terhadap kinerja instansi Kantor Inspektorat Aceh.

2. Akuntabilitas secara parsial berpengaruh terhadap kinerja instansi Kantor Inspektorat Aceh dengan nilai koefisien regresi sebesar 0,155. Hasil penelitian ini akan memberikan dampak bahwa akuntabilitas akan memberikan dampak nyata terhadap peningkatan kinerja instansi Kantor Inspektorat Aceh.

Transparansi berpengaruh secara parsial terhadap kinerja instansi para auditor pada Kantor Inspektorat Aceh dengan nilai koefisien regresi sebesar 0,137. Hasil penelitian ini memberikan implikasi bahwa dengan transparansi yang dimiliki oleh auditor akan memberikan pengaruh nyata dalam meningkatkan kinerja instansi bagi auditor Kantor Inspektorat Aceh.

\section{DAFTAR PUSTAKA}

Abdol M., Mohammad dan A. Wright. (2011). An Examination of The Effects of Experience and Task Complexity on Audit Judgements, The Accounting Revie, 1-3.

Anis, C. (2015). Pengaruh Kompetensi dan Independensi Terhadap Kelangsungan Usaha Kantor Akuntan Publik (KAP) di Malang. Jurnal Akuntansi dan Keuangan Balance. Vol.2(4)

Antle, R. (2013). Auditor Independence. Journal of Accounting Research. Spring. p. 1-20.

Arikunto, S. (2015). Prosedur Penelitian : Suatu Pendekatan Praktek edisi revisi IV, Jakarta : Rineka Cipta.

Arrens, Elder, Beasley. (2011). Auditing Dan Pelayanan Verifikasi. Edisi Kesembilan: Edisi Indonesia. PT. Indeks. 
Barnes dan Huan (2010). Financial Statement Analysis. Salemba Empat: Jakarta

Bernardi Richard A. (2011). Fraud Detection: The Effect of Client Integrity and Competence and Auditor Cognitive Style. Journal of Practice \& Theory, Vol.13, 68-84.

Budi, Sasongko. (2015). Internal Auditor dan Dilema Etika. Thesis S2, Akuntansi. Program Studi Magister Akuntansi Universitas Airlangga.

Christiawan, Y. Jogi. (2015). Kompetensi dan Independensi Akuntan Publik: Refleksi Hasil Penelitian Empiris. Journal Directory : Kumpulan Jurnal Akuntansi dan Keuangan Unika Petra, Vol.4(2)

De Angelo, L.E. (2010). Auditor Independence, "Low Balling", and Disclousere Regulation. Journal of Accounting and Economics 3. 113-127.

Deis, D.r. dan G.A. Groux. (2012). Determinants of Audit Quality in The Public Sector. The Accounting Review. 462-479.

Djamil, N. (2015). Faktor-faktor yang Mempengaruhi Kualitas Audit Pada Sektor Publik dan BEberapa Karakteristik Untuk Meningkatkanya. Media Akuntansi, June 27, 2015.

Grahani, I. (2015). Analisis pengaruh Independensi, Locus of Control, dan pengembangan Moral Auditor terhadap Pendeteksian Kecurangan (Fraud Auditing). Skripsi S1, Akuntansi. Fakultas Ekonomi Universitas Brawijaya.

Halim A. (2014). Akuntansi Keuangan Daerah, Edisi Pertama. Jakarta: Penerbit Salemba Empat.

Halim, A. (2015). Auditing 1 ( Dasar-dasar Audit Laporan Keuangan). Yogyakarta: AMP YKPN.

Hollingsworth, B.A. (2013). Validating Auditors' Assumptions : A Measure of the Quality of Performance. Journal of Business and Economics Research, Oktober.

Ikatan Akuntan Indonesia. (2015). Standar Profesional Akuntan Publik. Salemba Empat, Jakarta.

Jayanti, I.P., Sjamsuddin, S., dan Wachid, A. (2014). Reformasi Pengelolaan Keuangan Daerah dalam Rangka Mewujudkan Transparansi dan Akuntabilitas (Studi pada Pemerintah Kota Malang). Jurnal Administrasi Publik, Vol.2(2). 300-305.

Kusharyanti (2015), Temuan Penelitian Mengenai Kualitas Audit dan Kemungkinan Topik Penelitian di Masa Datang. Vol. 8 / No. 4.

Lastanti, H.S., (2015). Tinjauan Terhadap kompetensi dan Independensi Akuntan publik : Refleksi Atas Skandal Keuangan. Media Riset Akuntansi, Auditing dan Informasi, Vol.5(1)

Loina, K. (2013). Teori Akuntansi: Perekayasaan Pelaporan Keuangan edisi ketiga. Yogyakarta: BPFE.

Ludigdo, U. (2011). Strukturasi Praktik Etika di Kantor akuntan Publik: Sebuah Studi Interpretif. Simposium Nasional Akuntansi (SNA) 9 Padang.

Mahmudi (2014), Peranan Sistem Akuntansi Pemerintah Pusat Dalam Meningkatkan Akuntabilitas Keuangan dan Implikasi UU No. 22/25 Tahun 1999. Lintasan Ekonomi, Vol.XIX(1), 50-66.

Mardiasmo (2013), Reformasi Pengelolaan Keuangan Publik Menuju Akuntabilitas Publik, Makalah yang disampaikan dalam Kongres Ikatan Sarjana Ekonomi Indonesia (ISES), Makasar 21-23 April 2000 Hal 248-265 No. 12 
Maryani, T. dan Ludigdo, U. (2015). Survei Atas Faktor-faktor yang Mempengaruhi Sikap dan Perilaku Etis Akuntan. TEMA, Vol.II(1) 49-62.

Mayangsari, S. (2015). Analisis Pengaruh Independensi, Kualitas Audit, serta Mekanisme Corporate Governance terhadap Integritas Laporan Keuangan. Simposium Nasional Akuntansi (SNA) 6 Surabaya.

Mayangsari, S. (2015). Pengaruh Keahlian Audit dan Independensi terhadap Pendapat Audit: Sebuah Kuasieksperiman. Journal Riset Akuntansi Indonesia, Vol.6(1)

Muhammad dan I Putu. (2015). Akuntabilitas, Transparansi, Dan Anggaran Berbasis Kinerja Pada Satuan Kerja Perangkat Daerah Kota Denpasar. E-Jurnal Akuntansi Universitas Udayana, Vol.11(2), 611-628

Mulyadi. (2015). Auditing, jilid 1, edisi 6. Penerbit Salemba Empat, Jakarta.

Murtanto dan Gudono. (2015). Identifikasi Karakteristik-karakteristik Keahlian Audit: Profesi Akuntan Publik di Indonesia. Jurnal Riset Akuntansi Indonesia, Vol.2(1).

Natak, R. (2016). Analisis Pengaruh Akuntabilitas Dan Transparansi Pengelolaan Keuangan Daerah Terhadap Kinerja Pemerintah Daerah Kabupaten Jember. Artikel Ilmiah Mahasiswa 2016. Jurusan Akuntansi.

Nugrahaningsih, P. (2015). Analisis Perbedaan Perilaku Etis Auditor di KAP Dalam Etika Profesi (Studi Terhadap Peran Faktor-Faktor Individual: Locus of Control, Lama Pengalaman Kerja, Gender dan Equity Sensitivity). Simposium Nasional Akuntansi VIII. Solo.

Purnamasari, V.St. (2011). Sifat Machiavellian dan Pertimbangan Etis: Anteseden Independensi dan Perilaku Etis Auditor. Simposium Nasional Akuntansi (SNA) 9 Padang.

Purnomo, A. (2015). Persepsi auditor tentang pengaruh faktor-faktor keahlian dan independensi terhadap kualitas audit.

Putu, S.F. dan Juliarsa, G. (2014). Pengaruh independensi, profesionalisme, tingkat pendidikan, etika profesi, pengalaman, dan kepuasan kerja auditor terhadap kualitas audit pada kantor akuntan publik di Bali. E-Jurnal Akuntansi Universitas Udayana, Vol.8(1), 41-58.

Rachmati, L. (2011). "Independence In Fact, Independence In Appearance Dan Independence In Competence Terhadap Kualitas Audit Pada Kantor Akuntan Publik Di Surabaya". Jurnal Ilmiah Akuntansi.

Schwartz. (2015). Teoritical Perspective for Strategic Human Resource Management “. Journal of Management. 295-320.

Supriyanto, S. Pengaruh Kinerja Keuangan Terhadap Pendapatan Saham Perbankan Di Bursa Efek Indonesia. Jurnal Bis-A: Jurnal Bisnis Administrasi, Vol.2(1), 39-53.

Supriyono. (2011)., Manajemen Keuangan Daerah di Era Otonomi, Usahawan

Suraida, I. (2015). Pengaruh Etika, Kompetensi, Pengalaman Audit dan Resiko Audit Terhadap Skeptisisme Profesional Auditor dan Ketepatan Pemberia Opini Akuntan Publik. Sosiohumaniora, Vol.7(3), November.

Sopanah dan Mardiasmo. (2013). Pengaruh Partisipasi Masyarakat dan Transparansi Kebijakan Publik Terhadap Hubungan antara Pengetahuan Dewan Tentang Anggaran dengan Pengawasan Keuangan Daerah. Proceding Simposium Nasional Akuntansi VI , 1160-1173. 
Widagdo, R.S., Lesmana, dan S.A. Irwandi. (2015). Analisis Pengaruh Atribut-atribut Kualitas Audit Terhadap Kepuasan Klien (Studi Empiris pada Perusahaan yang Terdaftar di Bursa Efek Jakarta). Simposium Nasional Akuntansi (SNA) 5 Semarang.

Widayanti Anna Retno dan Subekti, Imam. (2015). Analisis Keahlian Auditor BPK-RI Menuju Pelaksanaan Fraud Auditing. Telaah Ekonomi, Manajemen dan Akuntansi. Vol.II(2).

Yulius J.C. (2015). Kompetensi dan Independensi Akuntan Publik : Refleksi Hasil Penelitian Empiris. 